\title{
Результати хірургічного лікування аноректальних вад розвитку у дітей
}

\author{
С. В. Веселий, Р. П. Кліманський
}

Донецький національний медичний університет, м. Лиман

\section{Results of surgical treatment of anorectal failures of development in children}

\author{
S. V. Veselyy, R. P. Klimanskyi
}

Donetsk National Medical University, Lyman

\section{Реферат}

Мета. Оцінити віддалені результати хірургічного лікування аноректальних вад розвитку (АВР) у дітей з урахуванням анамнестичних даних.

Матеріали і методи. Проаналізовано результати обстеження та хірургічного лікування 32 пацієнтів з АВР за останні 6 років.

Результати. Оперативні втручання у дітей виконували в залежності від форми аноректальної вади. Післяопераційні ускладнення спостерігали у 9 (28,1\%) із 32 пацієнтів, оперованих з приводу атрезії анального отвору та прямої кишки. Померли 2 (6,3\%) недоношених дітей з супутніми вадами розвитку.

Висновки. У дітей із вродженими АВР та ускладненим передопераційним періодом (недоношеність, супутні вади розвитку, внутрішньоутробна інфекція тощо) клінічний перебіг захворювання характеризувався великою кількістю різноманітних післяопераційних ускладнень у порівнянні з дітьми без обтяжливого анамнезу. Загальний стан дітей даної групи був значно тяжчим, вони потребували більш тривалої та інтенсивної передопераційної підготовки.

ключові слова: аноректальні вади розвитку; пряма кишка; атрезія; проктопластика; діти.

\section{Abstract}

Objective. To estimate a far remote results of surgical treatment of anorectal failures of development (ARFD) in children, taking into account the anamnesis data.

Materials and methods. Results of examination and surgical treatment of 32 patients with ARFD during last 6 yrs were analyzed. Results. Operative interventions in children were conducted, depending on the ARFD form presented. Postoperative complications were observed in 9 (28.1\%) of 32 patients, operated for the anal orifice and rectal atresia. In total 2 (6.3\%) patients died, who were premature babies with combined failures of development.

Conclusion. In children with the inborn ARFD and complicated preoperative period (prematurity, combined failures of development, intrauterine infection etc.) the disease clinical course was characterized by large quantity of various morbidity, comparing with children without complicated anamnesis. General state in children of this group was significantly severe, they needed more durable and intensive preoperative preparation.

Keywords: anorectal failures of development; rectum; atresia; proctoplasty; children.

Аноректальні вади розвитку (АВР) є досить поширеною вродженою патологією, ї констатують з частотою одне спостереження на 4000 - 5000 новонароджених. За даними ряду авторів, у 38 - 44\% новонароджених спостерігають поєднані вади розвитку, частіше сечостатевої, серцево-судинної, кістково-м'язової систем. Крім того, аноректальна атрезія є складовою VACTERL-асоціації. Характер хірургічного лікування даної вади залежить від висоти атрезії, наявності нориць, супутньої патології та загального стану немовляти - його зрілості, гострої патології періоду новонародженості тощо [1 - 4].

Алгоритм хірургічної тактики при АВР є таким. За низької форми атрезії та задовільного стану новонародженого, коли можлива радикальна операція, реконструкцію виконують одноетапно в ранньому неонатальному періоді. Багато авторів зазначають гарні функціональні результати ранньої корекції вади розвитку. За наявності широких нориць оперативне лікування без накладання превентивної колостоми відкладають на 1 - 2 міс. У всіх інших спостереженнях - висока атрезія прямої кишки, клоака, уроректальні сполучення - першим етапом безсумнівно рекомендують накладати превентивну колостому. Радикальний етап хірургічного лікування виконують протягом першого півріччя життя хворого. У виборі методу проктопластики провідну роль відіграє можливість зберегти утримуючу функцію (континенцію) і самостійну регуляцію акту дефекації [5 - 8].

В останні роки в дитячій колопроктології стали широко використовувати лапароскопічну мобілізацію прямої кишки з виділенням та перетинанням високих нориць. Це дає змогу точно звести кишку через центр промежини і волокна леватора, зберігаючи принцип мінімальної інвазивності як на абдомінальному, так і на промежинному етапі [9 - 11].

За даними K. Kyrklund і співавторів, після первинної пластики у 93\% хворих з низькими формами аноректаль- 
ної атрезії отримано гарні функціональні результати, після етапного лікування високих і проміжних форм частота хороших результатів становила 58\%, задовільних - 38\%, незадовільних - 4\%. Функціональні порушення затульного апарату прямої кишки після радикальної корекції АВР, які виникають у 30 - 60\% хворих, призводять до труднощів соціальної адаптації дітей у суспільстві [12].

Мета дослідження: оцінити віддалені результати хірургічного лікування АВР у дітей з урахуванням анамнестичних даних.

\section{Матеріали і методи дослідження}

За останні 6 років у клініці дитячої хірургії Донецького національного медичного університету проведено обстеження та лікування 32 пацієнтів з АВР. Хлопчиків було 14 (43,8\%), дівчаток - 18 (56,3\%). У 10 (31,3\%) новонароджених була висока форма атрезії прямої кишки, у 5 (15,6\%) проміжна, у 14 (43,8\%) - низька, у 2 (6,3\%) - промежинна ектопія ануса та у 1 (3,1\%) - анальна мембрана. У 14 (43,8\%) пацієнтів діагностована норицева форма аноректальної атрезії. Нориці у піхву були у 3 (9,4\%) новонароджених, у присінок піхви - у 7 (21,9\%), на промежину - у 4 (12,5\%).

3 ускладненням у вигляді перфорації сигмоподібної кишки та меконієвим перитонітом, що було пов'язано 3 пізньою діагностикою вади розвитку, госпіталізовано 2 (6,3\%) пацієнтів. Госпіталізовані в першу добу життя 26 (81,35\%) дітей, у них діагноз відсутності анального отвору у типовому місці зазвичай не викликав труднощів під час уважного огляду промежини. Госпіталізовані пізніше 6-ї доби життя 6 (18,7\%) новонароджених. Вони мали норицеві форми аноректальної атрезії, у них пряма кишка частково або достатньо спорожнялась.

Недоношеними були 6 (18,7\%) новонароджених з АВР. Пренатально в жодному спостереженні атрезія анального отвору та прямої кишки не була діагностована.

Усім хворим під час госпіталізації, окрім загальноприйнятих лабораторних та біохімічних досліджень (загальний аналіз крові та сечі, визначення групи крові та резус-фактора, рівнів загального білка і білкових фракцій, електролітів крові, коагулограма), застосовували спеціальні методи дослідження. Інвертографію за Вангестином проводили шляхом маркірування нормативного анального отвору предметом з високим коефіцієнтом рентгенівських променів. За відстанню між газовим міхуром (сліпий кінець атрезованої кишки) і міткою на промежині судили про висоту атрезіі. За наявності ректальних фістул виконували фістулографію.

Після обстеження у 21 (65,6\%) новонародженого з АВР констатували супутні вроджені вади розвитку. Найчастіше діагностували вроджені вади серцево-судинної системи - у 8 (25,0\%) дітей. Вади розвитку урогенітальної системи (гідронефроз, гіпоспадія, уретерогідронефроз) спостерігали у 3 (9,4\%) дітей, кісткові аномалії (клишоногість тяжкого ступеня, вроджений вивих стегна) - у 2 (6,3\%), вади розвитку центральної нервової системи - у 2 (6,3\%), незрощення піднебіння - у 52 (6,3\%), синдром Дауна - у 2 (6,3\%), діафрагмальну грижу - у 1 (3,1\%), кісту печінки - у 1 (3,1\%) дитини.

За даними серологічних та молекулярно-біологічних методів дослідження встановили, що 9 (28,1\%) новонарод- жених були внутрішньоутробно інфіковані. Інфекційний пейзаж включав такі агенти: Herpes Simplex Virus - у 2 (6,3\%) дітей, Cytomegalovirus - у 3 (9,4\%), Epstein-Barr Virus - y 1 (3,1\%), Chlamydia trachomatis - y 2 (6,3\%), Toxoplasma gondii y $-1(3,1 \%)$.

\section{Результати}

Залежно від форми аноректальної вади виконували різні оперативні втручання. Тривалість підготовки залежала від віку дитини, тяжкості стану та наявності супутніх вад розвитку. 3 приводу форм аноректальної атрезії виконували промежинну або задньосагітальну проктопластику. Новонародженим з проміжними та високими формами атрезії прямої кишки накладали колостому у вигляді anus preter naturalis на рухому петлю сигмоподібної кишки, основний етап хірургічної корекції виконували у віці від 3 - 6 до 9 міс у залежності від часу повторної госпіталізації дитини. Таким чином, декомпресійна колостома була накладена 9 (28,1\%) дітям, промежинна аноректопластика виконана 23 (71,9\%) дітям, у тому числі промежинна аноректопластика за Дифенбахом - 8 (25,0\%), задньосагітальна аноректопластика за Пеном - 15 (46,9\%). У 9 (28,1\%) пацієнтів після накладання колостоми в подальшому була виконана черевно-промежинна аноректопластика.

Показаннями до виконання етапного хірургічного втручання, тобто накладання колостоми в періоді новонародженості, були: високі та проміжні форми аноректальної атрезії наявність ректоуретральних та ректовагінальних нориць, інших складних вад розвитку, які потребували хірургічної корекції у невідкладному порядку (діафрагмальна грижа, вади серця тощо); тяжкий загальний стан новонародженого (недоношеність, незрілість, неврологічна патологія тощо).

Ректовестибулярну норицю у більшості пацієнтів вдавалося розбужувати бужами Гегара до діаметра, необхідного для достатнього спорожнення кишечника. У хворих 3 перинеальною норицею, анальною мембраною зазвичай достатньо було стандартного бужування. Бужі підбирали в такий спосіб: у віці $1-4$ міс використовували буж №811 Fr; 4 - 8 міс - буж №12-14 Fr; 8 - 12 міс - буж № 14 Fr. Щодня поступово виконували калібрування та бужування до досягнення вікового розміру. Після досягнення вікового розміру бужування виконували щодня протягом 1 міс, упродовж наступного періоду спостереження (реабілітаціi) - 2 - 3 рази на тиждень. У 2 (6,2\%) хворих виникла необхідність мобілізації нориці і переміщення эї до центру зовнішнього сфінктера. У 3 (9,3\%) хворих з низькою атрезією та ректоперинеальною норицею виконали сфінктерозберігаючу аноректопластику. У 3 (9,3\%) хворих операція була виконана на 3 - 4-му міс життя.

У післяопераційному періоді використовували стандартну програму реабілітації хворих, яка включала систематичне бужування неоануса, електростимуляцію м'язів промежини, масаж, ЛФК. Перший етап реабілітації хворі проходили відразу після операції, наступні етапи - під час планових госпіталізацій до стаціонару. Клінічний результат оцінювали через $1-2$ роки після закінчення всіх етапів хірургічної корекції та проведення реабілітаційної терапії. Через 2 - 3 тиж після загоєння післяопераційної 
рани виконували бужування неоануса бужами Гегара до розміру № 8-10 Fr, дитину виписували, навчивши матір інструментальному та пальцьовому бужуванню неоануса.

\section{Обговорення}

За наявності аноректальної атрезії з ректовестибулярною норицею визначали більш пізні терміни оперативного втручання. Однак невеликий отвір нориці не може забезпечувати адекватне спорожнення. Це призводить до розвитку мегаректосигмоїду, утворення калових каменів вторинної зміни стінки прямої кишки (порушення іннервації, склерозування), а в подальшому - до порушень акту дефекації. Тому навіть за наявності досить ефективної дефекації через вестибулярну норицю ми віддавали перевагу ранній корекції аномалії - до 2 - 3 міс життя, до формування мегаректуму. Методом вибору оперативного втручання була промежинна аноректопластика за Дифенбахом та задньосагітальна аноректопластика за Пеном.

Ускладнення після виконання операцій з приводу атрезії анального отвору та прямої кишки спостерігали у 9 $(28,1 \%)$ із 32 пацієнтів. У 5 (15,6\%) дітей виник гнійно-запальний процес у ділянці післяопераційної рани. Таким дітям, крім загальної антибактеріальної терапії, проводили місцеве лікування, яке полягало в механічному очищенні рани від гною і некротичних тканин, застосуванні антисептичних розчинів. У разі виникнення лігатурної нориці видаляли лігатуру, яка провокувала ії формування. В подальшому норицевий хід обробляли антисептиками 3 накладанням мазевих пов'язок.

У 4 (12,5\%) дітей через ускладнення перебігу захворювання ранньою спайковою кишковою непрохідністю виконали релапаротомію, ревізію кишечника та розділення зрощень переважно гострим шляхом. У дітей з повною ранньою спайковою кишковою непрохідністю перешкода мала обтураційний характер. Найбільш часто зміни в тонкій кишці спостерігали у вигляді фіксованих перегинів і «двостволок». Зрощення у цієї категорії хворих були вельми пухкими, їх легко роз'єднували. Після відновлення прохідності визначали життездатність кишечника, звертаючи увагу на колір, тонус, перистальтику кишки, пульсацію судин брижі. Оцінювали динаміку зазначених симптомів тричі: в момент ревізії, після усунення морфологічного субстрату непрохідності та після проведення реабілітаційних заходів (накладення теплих вологих компресів, інфільтрація брижі кишки розчином новокаїну, у разі необхідності - деторзія кишечника тощо). Великого значення надавали симптому «шовкової підкладки», який виникає у разі розшарування слизово-підслизового та м'язового шарів стінки кишки. Якщо просвіт кишкової трубки під час операції не розкривався, евакуацію кишкового вмісту здійснювали шляхом антеградного або ретроградного «видоювання» 3 наступною аспірацією через зонд. У 1 хворого по ходу хірургічного втручання було виконано розтин просвіту кишки та ретроградну інтубацію приводного відділу з подальшою активною аспірацією. Цю маніпуляцію виконували в умовах ретельного обмеження операційного поля. Для декомпресії верхніх відділів травного каналу в післяопераційному періоді застосовували інтубацію шлунка та тонкої кишки. Встановлений зонд утриму- вали до зникнення проявів парезу кишечника.

Всі ускладнення після хірургічної корекції вроджених АВР спостерігали лише на тлі недоношеності, супутньої вродженої патології та внутрішньоутробного інфікування.

Із 32 пацієнтів з вродженими АВР померли 2 (6,3\%): 1 - у віці 3 міс після радикальної операції та 1 - у віці 1 міс після радикальної операції через морфофункціональну незрілість та тяжку супутню патологію.

Таким чином, у хворих з вродженими вадами анального отвору та прямої кишки, які отримали комплекс діагностичних, лікувальних та реабілітаційних заходів, післяопераційні ускладнення були спричинені лише обтяжливим передопераційним анамнезом. Ці діти перебували на стаціонарному лікуванні на 5,2 ліжко-дня довше. В середньому тривалість стаціонарного лікування цих дітей становила $(26,1 \pm 0,94)$ ліжко-дня, дітей без обтяжливого передопераційного анамнезу - $(20,9 \pm 0,95)$ ліжко-дня.

\section{Висновки}

1. У новонароджених з вродженими АВР та ускладненим передопераційним періодом (недоношеність, супутні вади розвитку, внутрішньоутробна інфекція тощо) клінічний перебіг захворювання характеризувався великою кількістю різноманітних післяопераційних ускладнень у порівнянні з дітьми без обтяжливого анамнезу. Загальний стан дітей даної групи був значно тяжчим, вони потребували більш тривалої та інтенсивної передопераційної підготовки.

2. У 28,1\% дітей з вродженими АВР виникли післяопераційні ускладнення. Ці діти перебували на стаціонарному лікуванні на 5,2 ліжко-дня довше.

3. Померли 2 (6,3\%) недоношених дітей з супутніми вадами розвитку.

\section{References}

1. Dworschak GC, Zwink N, Schmiedeke E, Mortazawi K, Mдrzheuser S, Reinshagen K, et al. Epidemiologic analysis of families with isolated anorectal malformations suggests high prevalence of autosomal dominant inheritance. Orphanet J Rare Dis. 2017 Dec 13;12(1):180. doi: 10.1186/s13023-017-0729-7.

2. Khanna K, Sharma S, Pabalan N, Singh N, Gupta DK. A review of genetic factors contributing to the etiopathogenesis of anorectal malformations. Pediatr Surg Int. 2018 Jan;34(1):9-20. doi: 10.1007/s00383-017-4204-2.

3. Wood RJ, Levitt MA. Anorectal Malformations. Clin Colon Rectal Surg. 2018 Mar;31(2):61-70. doi: 10.1055/s-0037-1609020.

4. Ojmyr-Joelsson M, Frenckner B, Rydelius PA, Nisell M. Children with high and intermediate imperforate anus: their experience of hospital care. Pediatr Surg Int. 2011 Oct;27(10):1117-22. doi: 10.1007/s00383011-2927-Z.

5. Cairo SB, Gasior A, Rollins MD, Rothstein DH. Challenges in transition of care for patients with anorectal malformations: a systematic review and recommendations for comprehensive care. Dis Colon Rectum. 2018 Mar;61(3):390-9. doi: 10.1097/DCR.0000000000001033.

6. Reck-Burneo CA, Vilanova-Sanchez A, Wood RJ, Levitt MA, Bates DG. Imaging in anorectal and cloacal malformations. Pediatr Radiol. 2018 Mar;48(3):443-4. doi: 10.1007/s00247-017-4040-5.

7. Maghrebi H, Ksantini R, Makni A, Slama H, Jrad M, Daghfous A, et al. Anal imperforation in adults: Diagnostic difficulties and therapeutic options. Tunis Med. 2016 Nov;94(11):691. PMID: 28994873.

8. Cairo SB, Rothstein DH, Harmon CM. Minimally invasive surgery in the management of anorectal malformations. Clin Perinatol. 2017 Dec;44(4):819-34. doi: 10.1016/j.clp.2017.08.007.

9. Bischoff A, Levitt MA, Pena A. Laparoscopy and its use in the repair of anorectal malformations. Pediatr Surg Int. 2015 May;31(5):431-7. doi: 
10.1007/s00383-015-3687-y

10. De Vos C, Arnold M, Sidler D, Moore SW. A comparison of laparoscopic-assisted (LAARP) and posterior sagittal (PSARP) anorectoplasty in the outcome of intermediate and high anorectal maiformations. S Afr J Surg. 2011 Mar14;49(1):39-43. PMID: 21933483.

11. Xiao H, Chen L, Liu S, Li X, Diao M, Li L. Comparison of laparoscopic-assisted anorectoplasty and posterior sagittal anorectoplasty for high and intermediate anorectal malformations. Zhonghua Wei Chang Wai Ke Za Zhi. 2018 Jan 25;21(1):68-72. PMID: 29354902.

12. Kyrklund K, Pakarinen MP, Rintala RJ. Long-term bowel function, quality of life and sexual function in patients with anorectal malformations treated during the PSARP era. Semin Pediatr Surg. 2017 Oct;26(5):33642. doi: 10.1053/j.sempedsurg.2017.09.010.

Запорізька медична академія післядипломної освіти МОЗ України, Департамент охорони здоров'я Запорізької ОДА, Асоціація хірургів України

\section{6-17 травня 2019 р. у м. Запоріжжя проводять}

Всеукраїнський симпозіум з міжнародною участю

\section{НОВІТНІ ТЕХНОЛОГІЇ В ДІАГНОСТИЦІ ТА ЛІКУВАННІ СЕПСИСУ}

\section{Тематичні напрямки симпозіуму:}

Сепсис у хворих із гнійно-некротичними процесами м'яких тканин;

Абдомінальний сепсис. Сучасний стан проблеми;

Панкреатогенний та холангіогенний сепсис;

Гнійно-септичні ускладнення при бойовій та вогнепальній травмі;

Антибіотикопрофілактика та емпірічна антибіотикотерапія в хірургії, питання антибіотикорезистентності;

Судинний, опіковий сепсис та сепсис в торакальній хірургії;

Сепсис в ортопедично-травматологічній практиці;

Діабетична стопа;

Сепсис у онкологічних хворих;

Знеболення у хворих на хірургічний сепсис та принципи інтенсивної терапії

Симпозіум внесений до «Реєстру з'їздів, конгресів, симпозіумів, науково-практичних конференцій, які проводитимуться у 2019 році» за №7, що затверджений МОЗ та АМН України.

До участі у симпозіумі запрошують фахівців хірургічного профілю та інтенсивістів.

Роботи, прийняті до друку, будуть опубліковані в журналі «Сучасні медичні технології», який входить до переліку фахових видань, в яких можуть публікуватися результати дисертаційних робіт.

Журнал буде виданий учасникам симпозіуму разом із сертифікатом про участь (з бальною оцінкою).

Вартість публікації однієї сторінки статті складає 80 грн.

Статті разом з квитанцією про оплату надсилати за адресою:

Редакція журналу «Сучасні медичні технології». Бульвар Вінтера, 20, м. Запоріжжя 69096

$$
\text { Тел/факс: } 8 \text { (061) 289-80-82 E-mail:mmtzmapo@gmail.com }
$$

Статті слід надсилати до 01.04.2019 р.

3 правилами оформлення статей та іншою інформацією детально можна ознайомитися на сайті журналу: www.zmapo_jornal.com.ua 